\title{
Nursing diagnosis Risk for Falls in the elderly in primary health care
}

\author{
Diagnóstico de Enfermagem de Risco de Quedas em idosos da atenção primária \\ Diagnóstico de enfermería de Riesgo de Caídas en los ancianos en atención primaria
}

Paulo Henrique Fernandes dos Santos' ORCID: 0000-0003-4533-0129

Marina Morato Stival' ORCID: 0000-0001-6830-4914

Luciano Ramos de Lima' ORCID: 0000-0002-2709-6335

Walterlânia Silva Santos' ORCID: 0000-0001-6266-8901

Cris Renata Grou Volpe ORCID: 0000-0002-3901-0914

Tania Cristina Morais Santa Barbara Rehem ORCID: 0000-0002-4491-1661

Silvana Schwerz Funghetto ORCID: 0000-0002-9332-9029

'Universidade de Brasília. Brasília, Distrito Federal, Brazil.

How to cite this article: Santos PHFS, Stival MM, Santos WS, Volpe CRG Rehem TCMSB, Funghetto SS. Nursing diagnosis Risk for Falls in the elderly in primary healthcare.

Rev Bras Enferm. 2020;73(Suppl 3):e20180826. doi: http://dx.doi.org/10.1590/0034-7167-2018-0826

Corresponding author:

Paulo Henrique Fernandes dos Santos E-mail:paulofs@unb.br

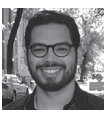

EDITOR IN CHIEF: Dulce Barbosa ASSOCIATE EDITOR: Marcos Brandão

Submission: 10-22-2018

Approval: 08-19-2019

\section{ABSTRACT}

Objective: to evaluate the Nursing Diagnosis (ND) Risk for Falls in elderly subjects in primary health care in the Federal District. Methods: a descriptive, quantitative, cross-sectional study conducted in two basic health units. Data collection included blood collection, nursing consultation and physical evaluation of 156 elderly subjects with chronic diseases. Results: the most prevalent intrinsic risk factors of NANDA-I were visual impairment (73.7\%), impaired mobility $(70.5 \%)$ and history of falls (69.9\%); and extrinsic factors were the use of insufficient material in the bathroom (60.3\%) and loose carpets (58.3\%). The intrinsic factors that increased the risk for falls were the use of assistive devices (OR 3.50; $p=0.030)$, impaired walking (OR 2.84; $\mathrm{p}=0.019$ ) and cognitive impairment ( $O R \quad 1.26 ; \mathrm{p}=0.019)$; and the extrinsic factor was the use of loose rugs (OR 1.59; $\mathrm{p}=0.041)$. Conclusion: this ND has proved to be a valuable instrument for the identification of risk factors for falls in elderly subjects in primary care.

Descriptors: Elderly; Accidents by Falls; Risk factors; Nursing Diagnosis; Primary Health Care.

\section{RESUMO}

Objetivo: avaliar o Diagnóstico de Enfermagem (DE) de Risco de Quedas em idosos da atenção primária do Distrito Federal. Métodos: estudo descritivo, quantitativo, transversal, realizado em duas unidades básicas de saúde. A coleta de dados compreendeu coleta de sangue consulta de enfermagem e avaliação física de 156 idosos com doenças crônicas. Resultados: os fatores de risco intrínsecos da NANDA-I mais prevalentes foram deficiência visual $(73,7 \%)$ mobilidade prejudicada $(70,5 \%)$ e história de quedas $(69,9 \%)$ e os fatores extrínsecos foram uso de material insuficiente no banheiro (60,3\%) e tapetes soltos (58,3\%). Os fatores intrínsecos que aumentaram o risco de quedas foram uso de dispositivos auxiliares ( $O R 3,50 ; p=0,030$ ), dificuldades na marcha ( $O R 2,84 ; p=0,019)$ e alteração na função cognitiva ( $O R$ 1,26; $p=0,019)$; e o extrínseco foi o uso de tapetes soltos ( $O R$ 1,59; $p=0,041)$. Conclusão: esse $D E$ se revelou uma ferramenta valiosa na identificação dos fatores de risco para quedas em idosos da atenção primária.

Descritores: Idoso; Acidentes por Quedas; Fatores de Risco; Diagnóstico de Enfermagem; Atenção Primária à Saúde.

\section{RESUMEN}

Objetivo: evaluar el Diagnóstico de Enfermería (ND) de Riesgo de Caídas en ancianos en atención primaria de salud en Distrito Federal. Métodos: investigación descriptiva, cuantitativa, transversal realizada en dos unidades básicas de salud. La recolección de datos incluyó recolección de sangre, consulta de enfermería y evaluación física de 156 ancianos con enfermedades crónicas. Resultados: los factores de riesgo intrínsecos más prevalentes de NANDA-I fueron la discapacidad visual (73.7\%), movilidad disminuida (70.5\%) y antecedentes de caídas (69.9\%); y los factores extrínsecos fueron el uso insuficiente de material en el baño (60.3\%) y alfombras sueltas (58.3\%). Los factores intrínsecos que aumentaron el riesgo de caídas fueron el uso de dispositivos de asistencia (OR 3.50; $p=0.030$ ), dificultades de la marcha (OR 2.84; $p=0.019$ ) y deterioro cognitivo (OR 1.26; $p=0,019$ ); y el factor extrínseco fue el uso de alfombras sueltas ( $O R$ 1.59; $p=0.041$ ). Conclusión: este ND ha demostrado ser una herramienta valiosa para identificar factores de riesgo de caídas en ancianos en atención primaria de salud.

Descriptores: Anciano; Accidentes por caídas; Factores de riesgo; Diagnóstico de Enfermería; Atención Primaria de Salud. 
Nursing diagnosis Risk for Falls in the elderly in primary health care Santos PHFS, Stival MM, Santos WS, Volpe CRG, Rehem TCMSB, Funghetto SS.

\section{INTRODUCTION}

The trend of population aging observed in recent decades, especially in developing countries, results from the demographic transition phenomenon consolidated with the reduction in mortality and fertility rates. In this scenario, the World Health Organization (WHO) estimates a world population of 1.2 billion people over 60 years of age in 2025 and 2 billion in 2050. By 2025, Brazil can be the sixth largest country in number of seniors, totaling about 32 million elderly in its population ${ }^{(1-2)}$.

The higher number of elderly individuals also brings a significant increase in noncommunicable chronic diseases (NCDs), such as systemic arterial hypertension $(\mathrm{SAH})$, diabetes mellitus (DM) and obesity. NCDs are considered a major public health problem and the leading cause of mortality worldwide. The scenario is also alarming in Brazil, since these diseases account for $71 \%$ of death causes ${ }^{(3)}$.

The morphological and physiological changes resulting from aging, associated with NCDs, predispose the elderly to episodes of falls. These are concerning events because of their high incidence, mortality and morbidity, in addition to social and economic costs resulting from falls. There is evidence of a high prevalence of falls among the elderly, which can result in serious consequences such as fractures, soft tissue injuries and death ${ }^{(4)}$.

Falls are events of multifactorial causes that can be intrinsic and extrinsic factors. Intrinsic factors include sociodemographic, cognitive, physiological and lifestyle aspects. Extrinsic factors include environmental aspects that contribute to episodes of falls. Identifying these risk factors is essential, since many of them are preventable ${ }^{(5)}$.

Among the instruments available for identifying the risk for falls in the elderly, the Nursing Diagnosis (ND) Risk for Falls is defined by the North American Nursing Diagnosis Association (NANDA) Taxonomy II as "vulnerability to increased susceptibility for falls, which can cause physical damage and compromise health"(6).

Although the literature has studies assessing the Risk for Falls ND in various health care contexts ${ }^{(7-8)}$, there is a gap of studies on the use of this ND in primary health care with community elderly. A larger number of studies was developed with institutionalized elderly.

Therefore, the present study is justified by the impact of the fall event on elderly individuals' health, especially those affected by NCDs, and by the need to improve the identification of risk factors for the occurrence of falls in community elderly. Given the relevant role of nursing in the promotion of self-care and prevention of health problems ${ }^{(9)}$, the application of the Risk for Falls ND can contribute both to the precise identification of factors that contribute to falls in the elderly, and to the prevention of these events.

\section{OBJECTIVE}

To evaluate the Nursing Diagnosis Risk for Falls in the elderly of primary health care in the administrative region of Ceilândia - Federal District.

\section{METHODS}

\section{Ethical aspects}

This project is part of a larger project called "Approach to chronic noncommunicable conditions in primary health care", approved by the Research Ethics Committee of the Fundação de Ensino e Pesquisa em Ciências da Saúde (FEPECS). All participants signed the Informed Consent form (IC).

\section{Design, place of study and period}

Descriptive, quantitative, cross-sectional study based on part of the master's dissertation of one of the authors. The study was conducted in two Basic Health Units (Portuguese acronym: UBS) of Ceilândia, which is considered the largest administrative region of the Federal District. The data collection period was between February and July 2017.

\section{Population or sample: inclusion and exclusion criteria}

Random sampling was performed through a draw of elderly subjects registered in the Diabetic and Hypertensive groups of the health unit. For sample calculation, were considered a sampling error of $6.0 \%$, a confidence interval of $95 \%$ and a population size of 1,600, resulting in 196 elderly. For the selection of study participants, were considered the following inclusion criteria: age $\geq 60$ years, both sexes, with $\mathrm{DM}$ and/or SAH. Thirty elderly people were excluded because they met the criterion of inability to perform physical tests to assess the risk for falls, such as being in a wheelchair. In addition, ten elderly subjects did not agree to participate in the study, hence the final sample comprised 156 elderly individuals. The sample loss was $20 \%$, which is considered within the normal range.

\section{Study protocol}

The elderly selected were approached during the group meeting at the health unit. At this time, they were instructed to come to the health unit at a previously scheduled day and time, in a 12-hour fast. Upon arrival at the unit, they were advised on the study protocol and those who agreed to participate as volunteers signed the informed consent form. Initially, blood was drawn from the elderly for a complete blood count and blood glucose in order to identify risk factors related to changes in blood glucose level and anemia. Samples were obtained with puncture, preferably in the cubital vein, using vacuum tubes, and were sent for analysis in a private laboratory partner of the research group. Fasting glucose levels considered low were $\leq 70 \mathrm{mg} / \mathrm{dl}$, and those considered high were $\geq 126 \mathrm{mg} / \mathrm{dl}^{(10)}$. Hemoglobin values were considered altered when below $12 \mathrm{~g} / \mathrm{dl}$ for women and below $13 \mathrm{~g} / \mathrm{dl}$ for men ${ }^{(11)}$.

After blood collection, the elderly received breakfast and were referred to the nursing consultation that consisted of data collection for characterization of subjects, cognitive assessment and assessment of the Risk for Falls ND with duration of approximately 50 minutes. Consultations were held in the offices by nurses and nursing students (members of the study group), who were previously trained by researchers for the collection of data and 
performance of assessments. Consultations were performed with the sole purpose of collecting data for the study.

The instrument of characterization of elderly subjects included sociodemographic, clinical and lifestyle characteristics. The Anatomical Therapeutic Chemical (ATC) Classification, composed of thirteen classes of medications, was adopted to assess the use of medications. Cognitive assessment was performed by applying the Mini Mental State Examination (MMSE). The cutoff points used to identify cognitive changes, considering education, were: illiterate, 18 points; from 1 to 3 years of schooling, 21 points; 4-7 years of schooling, 24 points; more than 7 years of schooling, 26 points ${ }^{(12)}$.

For the assessment of the Risk for Falls ND, was built a checklist instrument containing the risk factors for falls involving the elderly, according to NANDA-I (2015-2017). Although in NANDA, the risk factors for falls are grouped into the categories "In adults", "In children", "Cognitive", "Environmental", "Pharmacological agents" and "Physiological", in this study, we chose to group them into intrinsic or extrinsic factors, as used in another study on this theme ${ }^{(13)}$.

In the grouping of risk factors, the category of child-related risk factors was not considered ${ }^{(6)}$. Risk factors in categories "In adults", "Cognitive", "Pharmacological agents" and "Physiological” were classified as intrinsic risk factors, while the "Environmental" category comprised extrinsic risk factors. The identification of risk factors for the Risk for Falls ND occurred through elderly subjects' self-reports, observation of the elderly by the evaluator, physical evaluation and laboratory parameters.

At the end of the nursing consultation, elderly individuals were directed to the external area of the health unit to assess the risk for falls through application of an instrument/physical tests, and to track peripheral neuropathy. This step lasted 30 minutes on average.

The following methods were used to identify the risk for falls: 1) The Fall Risk Score has a score ranging from 0 to 11 points. In this case, scores greater than or equal to 3 indicate a high risk for falls ${ }^{(14)}$; 2) The Berg Balance Scale (BBS) has a maximum score of 56 points. In this case, the lower the score achieved the higher the risk for falls; scores below 45 points indicate a high risk for falls and scores between 46 and 53 indicate low to moderate risk for falls ${ }^{(15)} ; 3$ ) The Timed Up-and-Go (TUG) is a test quantified in seconds, according to which the execution time up to 10 seconds is considered normal, 11-20 seconds indicates partial independence and low risk for falls, and a time greater than 20 seconds indicates significant physical mobility deficit and risk for falls ${ }^{(16)}$.

Screening for peripheral neuropathy consisted of investigating the loss of protective sensation (LPS) by the $10 \mathrm{~g}$ monofilament test and neurological tests (deep painful sensation, vibration sensation and Achilles reflex). To complete the diagnosis of loss of sensation, in addition to the absence of protective sensation, the patient should present one or more altered neurological tests ${ }^{(17)}$.

\section{Analysis of results and statistics}

For data analysis, was built a database with the Statistical Package for the Social Sciences (SPSS ${ }^{\circ}$ ), version 20.0. As for data related to the sample characterization, descriptive statistical analysis was performed using absolute, relative frequencies and dispersion measures (mean, standard deviation, minimum and maximum). Normal distribution was assessed by the Kolmogorov-Smirnov test. To compare means between the two groups, was performed the t-test. Risk factors were associated with the likelihood of occurrence of falls by calculating the Odds Ratio, its 95\% confidence interval $(\mathrm{Cl})$ and the $\mathrm{p}$-value. The significance level considered in this study was $p<0.05$.

\section{RESULTS}

In total, were evaluated 156 elderly, most of which were female (79.5\%), mean age of $67.9 \pm 5.8$ years. Elderly individuals aged 60 to 64 years corresponded to $34.0 \%$, followed by those aged 65 to 69 years $(31.4 \%)$, of mixed race $(52.6 \%)$, married $(51.3 \%)$ and inactive (41.7\%). Only 39.1\% were retired (Table 1 ).

Regarding education, the sample showed elderly people with few years of education, and $33.3 \%$ had from one to four years of schooling. Low income was prevalent among the elderly, who reported receiving less than or equal to one minimum wage (52.6\%). Regarding the number of residents in the house, $11.5 \%$ of the elderly lived alone, while the majority (29.5\%) lived with three people in the house (Table 1).

Table 1 - Sociodemographic characteristics of elderly subjects with chronic diseases (N=156), Brasília, Brazil, 2018

\begin{tabular}{|c|c|c|c|}
\hline Variable & Description & $\mathbf{n}$ & $\%$ \\
\hline Sex & $\begin{array}{l}\text { Female } \\
\text { Male }\end{array}$ & $\begin{array}{c}124 \\
32\end{array}$ & $\begin{array}{l}79.5 \\
20.5\end{array}$ \\
\hline Age (years) & $\begin{array}{l}60 \text { to } 64 \\
65 \text { to } 69 \\
70 \text { to } 74 \\
75 \text { to } 79 \\
\geq 80\end{array}$ & $\begin{array}{c}53 \\
49 \\
34 \\
12 \\
8\end{array}$ & $\begin{array}{c}34.0 \\
31.4 \\
21.8 \\
7.7 \\
5.1\end{array}$ \\
\hline Age & $(\mathrm{M} \pm \mathrm{SD} / \mathrm{Min} / \mathrm{Max})$ & \multicolumn{2}{|c|}{$67.9 \pm 5.8 / 60 / 85$} \\
\hline Marital status & $\begin{array}{l}\text { Single } \\
\text { Married } \\
\text { Divorced } \\
\text { Widowed } \\
\text { White }\end{array}$ & $\begin{array}{l}21 \\
80 \\
15 \\
40 \\
52\end{array}$ & $\begin{array}{c}13.5 \\
51.3 \\
9.6 \\
25.6 \\
33.3\end{array}$ \\
\hline Race & $\begin{array}{l}\text { Mixed race } \\
\text { Black }\end{array}$ & $\begin{array}{l}82 \\
22\end{array}$ & $\begin{array}{l}52.6 \\
14.1\end{array}$ \\
\hline Occupation & $\begin{array}{l}\text { Active } \\
\text { Inactive* }^{*} \\
\text { Retired** } \\
\text { Illiterate }\end{array}$ & $\begin{array}{l}30 \\
65 \\
61 \\
17\end{array}$ & $\begin{array}{l}19.2 \\
41.7 \\
39.1 \\
10.9\end{array}$ \\
\hline Schooling & $\begin{array}{l}1 \text { to } 4 \text { years } \\
5 \text { to } 8 \text { years } \\
\geq 9 \text { years }\end{array}$ & $\begin{array}{l}52 \\
52 \\
35\end{array}$ & $\begin{array}{l}33.3 \\
33.3 \\
22.5\end{array}$ \\
\hline Monthly income & $\begin{array}{l}\leq 1 \text { minimum wage } \\
2 \text { to } 3 \text { minimum wages } \\
\geq 4 \text { minimum wages }\end{array}$ & $\begin{array}{l}82 \\
61 \\
13\end{array}$ & $\begin{array}{c}52.6 \\
39.1 \\
8.3\end{array}$ \\
\hline Number of residents in the house & $\begin{array}{l}1 \\
2 \\
3 \\
4 \\
\geq 5\end{array}$ & $\begin{array}{l}18 \\
34 \\
46 \\
30 \\
28\end{array}$ & $\begin{array}{l}11.5 \\
21.8 \\
29.5 \\
19.2 \\
17.9\end{array}$ \\
\hline Nr. Residents in the house & (M \pm SD/Min./Max.) & $3.2 \pm 1$ & $6 / 1 / 9$ \\
\hline
\end{tabular}

Note: $n$ : number of participants; \%: percentage; M:Mean; SD:Standard Deviation; Min:Minimum Max: Maximum; \pm : More or less; $\geq:$ greater than or equal; $\leq$ less than or equal; Minimum Wage: the minimum wage in Brazil in 2017: $R \$ 937$; *does not perform any paid activity and does not receive a pension or retirement; **receives pension or retirement.

Most elderly subjects declared themselves non-smokers (92.3\%), non-alcoholics (94.2\%) and practitioners of physical activities (73.7\%). Regarding sleep habits, $44.9 \%$ reported changes in sleep (Table 2). Regarding comorbidities, $80.8 \%$ had hypertension, $59.6 \%$ 
had DM and $48.1 \%$ had both comorbidities (SAH and DM). Among diabetics, $10.9 \%$ used insulin. Regarding inflammatory diseases, $8.3 \%$ of the elderly said they had some diagnosis, and arthrosis and arthritis were the most common (Table 2). The majority used medication related to the cardiovascular system (84.6\%), followed by alimentary tract and metabolism drugs (64.1\%) (Table2).

Table 2 - Clinical characteristics and lifestyle habits of elderly subjects (N=156), Brasília, Brazil, 2018

\begin{tabular}{|c|c|c|}
\hline Variable & $\mathbf{n}$ & $\%$ \\
\hline \multicolumn{3}{|l|}{ Smoking } \\
\hline Yes & 12 & 7.7 \\
\hline No & 144 & 92.3 \\
\hline \multicolumn{3}{|l|}{ Alcoholism } \\
\hline Yes & 9 & 5.8 \\
\hline No & 147 & 94.2 \\
\hline \multicolumn{3}{|l|}{ Sedentary lifestyle } \\
\hline Yes & 41 & 26.3 \\
\hline No & 115 & 73.7 \\
\hline \multicolumn{3}{|l|}{ Sleep } \\
\hline Normal & 86 & 55.1 \\
\hline Altered & 70 & 44.9 \\
\hline \multicolumn{3}{|l|}{$\mathrm{SAH}$} \\
\hline Yes & 126 & 80.8 \\
\hline No & 30 & 19.2 \\
\hline \multicolumn{3}{|l|}{ DM } \\
\hline Yes & 93 & 59.6 \\
\hline No & 63 & 40.4 \\
\hline \multicolumn{3}{|l|}{ SAH and DM } \\
\hline Yes & 75 & 48.1 \\
\hline No & 81 & 51.9 \\
\hline \multicolumn{3}{|l|}{ Use of insuline } \\
\hline Yes & 17 & 10.9 \\
\hline No & 139 & 89.1 \\
\hline \multicolumn{3}{|l|}{ Inflammatory diseases } \\
\hline Yes & 13 & 8.3 \\
\hline No & 143 & 91.7 \\
\hline \multicolumn{3}{|l|}{ Medications* } \\
\hline A - alimentary tract and metabolism & 100 & 64.1 \\
\hline B - blood and hematopoietic system & 31 & 19.9 \\
\hline C - cardiovascular system & 132 & 84.6 \\
\hline G-hormonal preparations & 11 & 7.0 \\
\hline M-musculoskeletal system & 11 & 7.0 \\
\hline $\mathrm{N}$ - nervous system & 11 & 7.0 \\
\hline $\mathrm{R}$ - respiratory system & 4 & 2.5 \\
\hline
\end{tabular}

In this study, $71.2 \%$ of the elderly reported a history of falls. Regarding sex, females had a higher prevalence of falls, accounting for $83.5 \%$ of total falls. When analyzing the history of falls according to the age of elderly individuals, the age group with the highest prevalence of falls was that of 75 to 79 years old (75.0\%), followed by the group of 66 to 69 years old $(73.5 \%), 70$ to 74 years old $(70.6 \%)$, 60 to 65 years old $(66.0 \%)$, and lastly, those over 80 years old (62.5\%).

In the analysis of the number of the risk factors for the Risk for Falls ND according to the elderly's history of falls, a higher mean of risk factors (mean $=8.7$ ) was observed in elderly who had already fallen compared to the elderly with no history of falls (mean $=6.8)(p<0.000)$.

When investigating the Risk for Falls ND, the risk factors of elderly with chronic diseases were presented as intrinsic and extrinsic. The most prevalent intrinsic factors in elderly subjects of the "In adults" category, were history of falls (69.9\%) and age $\geq 65$ years $(66.0 \%)$. In the "Cognitive" category, $54.5 \%$ of the elderly had some cognitive impairment, either mild or moderate. In the category"Pharmacological agents", medications for the cardiovascular system were the most used by elderly subjects (84.6\%) (Table 3 ).

Regarding the category "Physiological", the most highlighted risk factors were visual impairment (73.7\%), impaired mobility (70.5\%) and sleep deprivation (47.4\%). The occurrence of falls was related to intrinsic risk factors, which demonstrates the significant association between the use of assistive devices such as walking stick, cognitive impairment, anemia and impaired walking, and the risk for falls (Table 3 ).

Regarding the category "In adults", the use of assistive devices by the elderly was related to the occurrence of falls, since $87.5 \%$ of elderly users of these devices had a history of falls. Furthermore, the use of the assistive device increases the risk for falls by 3.50 times $(p=0.030)$. In the category "Cognitive", elderly with cognitive impairment had a higher prevalence of falls (62.4\%). This risk factor increases by 1.26 times an elderly person's chance of fall $(p=0.030)$ (Table 3 ).

In the "Physiological" category, was observed an interesting fact in the anemia risk factor, since most anemic elderly people did not experience falls (71.4\%), thereby demonstrating a 2.5 times greater chance of not having episodes of falls $(p=0.026)$. Still in this category, impaired walking was higher in elderly people with a history of falls (84.2\%), thus increasing the risk for falls by 2.84 times $(p=0.019)$ (Table 3).

Table 3 - Association between intrinsic risk factors and the occurrence of falls and no falls in elderly subjects with chronic diseases, odds ratio (OR) and confidence interval (95\% Cl), Brasília, Brazil 2018

\begin{tabular}{|c|c|c|c|c|c|c|}
\hline Intrinsic risk factors & n (\%) & $\begin{array}{c}\text { Fall } \\
(\mathrm{n}=109) \\
(\%)\end{array}$ & $\begin{array}{c}\text { No fall } \\
(n=47) \\
(\%)\end{array}$ & OR & $95 \% \mathrm{Cl}$ & $\begin{array}{c}p \\
\text { value* }\end{array}$ \\
\hline \multicolumn{7}{|l|}{ In adults } \\
\hline \multicolumn{7}{|l|}{ History of falls } \\
\hline Age $\geq 65$ years & $103(66.0)$ & $74(71.2 \%)$ & $30(28.8 \%)$ & 1.19 & $0.58-2.45$ & 0.376 \\
\hline Living alone & $20(12.8)$ & 17(85.0) & $3(15.0)$ & 2.15 & $0.73-2.79$ & 0.089 \\
\hline Lower limb prosthesis & $1(0.6)$ & $1(100.0)$ & - & - & - & 0.699 \\
\hline Use of auxiliary devices & $24(15.4)$ & $21(87.5)$ & $3(12.5)$ & 3.50 & $1.6-7.8$ & 0.030 \\
\hline \multicolumn{7}{|c|}{ Cognitives } \\
\hline \multicolumn{7}{|c|}{ Change in cognitive function (MMSE) } \\
\hline Compromised MMSE & $85(54.5)$ & $53(62.4)$ & $32(37.6)$ & 1.26 & $1.03-1.55$ & 0.019 \\
\hline
\end{tabular}




\begin{tabular}{|c|c|c|c|c|c|c|}
\hline Intrinsic risk factors & n (\%) & $\begin{array}{c}\text { Fall } \\
(n=109) \\
(\%)\end{array}$ & $\begin{array}{c}\text { No fall } \\
(n=47) \\
(\%)\end{array}$ & OR & $95 \% \mathrm{Cl}$ & $\underset{\text { value }}{\boldsymbol{p}}$ \\
\hline \multicolumn{7}{|l|}{ Pharmacological agents } \\
\hline \multicolumn{7}{|l|}{ Pharmacological agent** } \\
\hline A - alimentary tract and metabolism & $100(64.1)$ & $67(67.0)$ & $33(33.0)$ & 1.26 & $0.22-2.71$ & 0.261 \\
\hline B - blood and hematopoietic system & $31(19.9)$ & $18(58.1)$ & 13(41.9) & 1.53 & $0.92-2.55$ & 0.080 \\
\hline C - cardiovascular system & $132(84.6)$ & $92(69.7)$ & $40(30.3)$ & 1.08 & $0.72-1.62$ & 0.443 \\
\hline G - hormonal preparations & $11(7.0)$ & $8(72.7)$ & $3(27.3)$ & 1.05 & $0.72-1.54$ & 0.545 \\
\hline M - musculoskeletal system & $11(7.0)$ & $8(72.7)$ & $3(27.3)$ & 1.05 & $0.72-1.54$ & 0.545 \\
\hline $\mathrm{N}$ - nervous system & $11(7.0)$ & $8(72.7)$ & $3(27.3)$ & 1.05 & $0.72-1.54$ & 0.545 \\
\hline $\mathrm{R}$ - respiratory system & $4(2.5)$ & $3(75.0)$ & $1(25.0)$ & 1.08 & $0.61-1.93$ & 0.638 \\
\hline Alcohol consumption & $9(5.8)$ & $4(44.4)$ & $5(55.6)$ & 0.62 & $0.29-1.30$ & 0.094 \\
\hline \multicolumn{7}{|l|}{ Physiological } \\
\hline \multicolumn{7}{|l|}{ Change in blood glucose level } \\
\hline Fasting blood glucose $\geq 126$ mg/dl (hyperglycemia) & $43(27.6)$ & $26(60.5)$ & $17(39.5)$ & 1.48 & $0.92-2.40$ & 0.084 \\
\hline Fasting blood glucose $<70$ mg/dl (hypoglycemia) & $3(1.9)$ & $3(100.0)$ & - & - & - & 0.338 \\
\hline Anemia & $7(4.5)$ & $2(28.6)$ & $5(71.4)$ & 2.5 & $1.48-4.32$ & 0.026 \\
\hline \multicolumn{7}{|l|}{ Women: $\mathrm{Hb}<12 \mathrm{~g} / \mathrm{dl}$} \\
\hline Arthritis & $30(19.2)$ & $25(83.3)$ & $5(16.7)$ & 2.00 & $0.86-4.62$ & 0.055 \\
\hline Sleep deprivation (yes or no) & $74(47.4)$ & & & & & \\
\hline Condition affecting the feet & $23(14.7)$ & $18(78.3)$ & $5(21.7)$ & 1.45 & $0.64-3.28$ & 0.245 \\
\hline Hearing impairment & 29 (18.6) & $21(72.4)$ & $8(27.6)$ & 1.11 & $0.58-2.12$ & 0.465 \\
\hline Visual impairment & $115(73.7)$ & 85 (73.9) & $30(26.1)$ & 2.00 & $0.95-4.24$ & 0.052 \\
\hline Proprioceptive deficit & - & - & - & - & - & - \\
\hline Fainting when extending the neck & $1(0.6)$ & - & $1(100.0)$ & - & - & 0.301 \\
\hline Fainting when turning the neck & - & - & - & - & - & - \\
\hline Diarrhea & $8(5.1)$ & $5(62.5)$ & $3(37.5)$ & 1.12 & $0.65-1.94$ & 0.452 \\
\hline Impaired walking & $38(24.4)$ & $32(84.2)$ & $6(15.8)$ & 2.84 & $1.09-4.77$ & 0.019 \\
\hline Acute disease & $3(1.9)$ & $2(66.7)$ & $1(33.3)$ & 1.04 & $0.46-2.35$ & 0.662 \\
\hline Vascular disease & $21(13.5)$ & $16(76.2)$ & $5(23.8)$ & 1.30 & $0.58-2.92$ & 0.345 \\
\hline \multicolumn{7}{|l|}{ Impaired Balance (BBS) } \\
\hline Normal (score $\geq 53$ points) & $88(56.4)$ & $64(72.7)$ & $24(27.3)$ & 1.45 & $0.69-3.0$ & 0.320 \\
\hline Low to moderate risk for falls (score $\geq 46$ and $\leq 52$ ) & $68(43.6)$ & $33(64.7)$ & $18(35.3)$ & - & - & - \\
\hline High risk for falls (score $<45$ ) & & $12(70.6)$ & $5(29.4)$ & 1.30 & $0.39-4.30$ & 0.657 \\
\hline Orthostatic hypotension & $23(14.7 \%)$ & $16(69.6)$ & $7(30.4)$ & 1.00 & $0.75-1.34$ & 0.575 \\
\hline Incontinence & $33(21.2 \%)$ & $26(78.8)$ & $7(21.2)$ & 1.53 & $0.75-3.10$ & 0.148 \\
\hline \multicolumn{7}{|l|}{ Impaired Mobility (TUG) } \\
\hline Normal (TUG - time $\leq 10$ seconds) & $46(29.5 \%)$ & $30(65.2)$ & $16(34.8)$ & - & - & - \\
\hline Low risk for falls (TUG - time $\geq 11$ to $\leq 20$ seconds) & $110(70.5)$ & $61(70.9)$ & $25(29.1)$ & 1.30 & $0.60-2.79$ & 0.499 \\
\hline High risk for falls (TUG - time $>20$ seconds) & & $18(75.0)$ & $6(25.0)$ & 1.60 & $0.52-4.83$ & 0.402 \\
\hline Neoplasia & - & - & - & - & - & - \\
\hline Postoperative Recovery Period & - & - & - & - & - & - \\
\hline Reduced strength in lower limbs & $32(20.5)$ & $26(81.3)$ & $6(18.7)$ & 1.76 & $0.82-3.78$ & 0.084 \\
\hline Urge urinary incontinence & $15(9.6)$ & $10(66.7)$ & $5(33.3)$ & 1.05 & $0.72-1.53$ & 0.491 \\
\hline
\end{tabular}

Note: OR: Odds Ratio; Cl: Confidence Interval; $p^{*}$ : p-value; MMSE: Mini Mental State Examination; HB: Hemoglobin; BBS: Berg Balance Scale; TUG: Timed Up-and-Go; \%: percentage; C: class of medicines; $\geq$ : greater than or equal; $\leq$ less than or equal; $>$ : greater than; $<$ : less than. ${ }^{*} p \leq 0.05 ;{ }^{* *}$ drug classes according to ATC classification.

Table 4 - Association between extrinsic risk factors and the occurrence of falls and no falls in elderly subjects with chronic diseases, odds ratio (OR) and confidence interval (95\% Cl), Brasília, Brazil, 2018

\begin{tabular}{|c|c|c|c|c|c|c|}
\hline Extrinsic risk factors & n (\%) & $\begin{array}{c}\text { Fall } \\
(\mathrm{n}=109) \\
(\%)\end{array}$ & $\begin{array}{c}\text { No fall } \\
(n=47) \\
(\%)\end{array}$ & OR & $95 \% \mathrm{Cl}$ & $\underset{\text { value* }}{p}$ \\
\hline \multicolumn{7}{|l|}{ Environmental } \\
\hline Disorganized or object-filled environment & $6(3.8)$ & $5(83.3)$ & $1(16.7)$ & 0.83 & $0.57-1.20$ & 0.414 \\
\hline Little known scenario & - & - & - & - & - & - \\
\hline Exposure to unsafe environmental condition (eg. wet floor, ice) & $11(7.1)$ & $7(63.6)$ & $4(36.4)$ & 1.10 & $0.69-1.74$ & 0.434 \\
\hline Insufficient lighting & $6(3.8)$ & $5(83.3)$ & $1(16.7)$ & 0.83 & $0.57-1.20$ & 0.414 \\
\hline Insufficient non-slip material in the bathroom & $94(60.3)$ & $67(71.3)$ & $27(28.7)$ & 0.95 & $0.76-1.17$ & 0.383 \\
\hline Use of immobilizers & $2(1.3)$ & $2(100.0)$ & - & - & - & 0.487 \\
\hline Use of loose rugs & $91(58.3)$ & $69(75.8)$ & $22(24.2)$ & 1.59 & $1.08-2.56$ & 0.041 \\
\hline
\end{tabular}

Note: OR: Odds Ratio; Cl: Confidence Interval; $p^{*}: p$-value; \%: percentage. ${ }^{*} p \leq 0.05$

When considering extrinsic risk factors, in the "Environmental" category, the most prevalent factors were the use of insufficient non-slip material in the bathroom (60.3\%), followed by use of loose carpets in the house (58.3\%). Elderly subjects who reported using loose carpets in their homes had a higher prevalence of falls (75.8\%), increasing by 1.59 times the chance of a fall event $(\mathrm{p}=0.041)$ (Table 4$)$. 


\section{DISCUSSION}

The results presented show the magnitude of the problem of falls in the elderly in the primary health care context and the high prevalence of history of falls. In addition, they demonstrate that using the Risk for Falls ND in conjunction with assessments and additional instruments represents an important strategy to identify intrinsic and extrinsic factors contributing to the occurrence of falls in this population in specific contexts.

When analyzing the sociodemographic characteristics of elderly subjects in this study, was observed a prevalence of females, older people of the younger age group, married, mixed race, who do not work, with few years of schooling, low income and who do not live alone. Similar results were found in a study conducted by the Center for Elderly Care of the Universidade Federal de Pernambuco with 150 diabetic elderly subjects attended in outpatient service ${ }^{(18)}$.

The higher prevalence of females in these studies corroborates data from the National Household Sample Survey (Portuguese acronym: PNAD-2012) of the Brazilian Institute of Geography and Statistics (Portuguese acronym: IBGE) ${ }^{(9)}$ and may be related to the fact of women being more careful with their health, which reflects greater access to health services and lower mortality ${ }^{(20)}$.

The low educational level of elderly subjects drew attention. In a study conducted with elderly people from Pelotas, Rio Grande do Sul, low education was inversely associated with the risk for falls. The impact of low education on elderly subjects' health may be related to a greater difficulty with accessing health services and a lower ability of understanding and taking advantage of information provided by health professionals regarding self-care and disease prevention, including falls ${ }^{(21)}$.

Regarding inappropriate life behaviors, the elderly presented disturbed sleep. In a study of elderly people from Singapore, Asia, in the context of primary health care, were evaluated the determinants of poor sleep quality in elderly people with cardiometabolic risk factors (DM, SAH, and hyperlipidemia). Nocturia was the only variable associated with a higher risk of poor sleep quality in participants ${ }^{(22)}$.

In this study, was identified a high prevalence of history of falls in the elderly. In a study of 724 elderly in Uberaba, Minas Gerais, was found a prevalence of falls of $28.3 \%$, lower than that observed in this study, more frequent in females and elderly over 80 years old, who had more than two comorbidities and used five or more medications. The high prevalence of history of falls found in this study can be explained by the inclusion of elderly people with NCDs in the sample. When associated with functional decline resulting from aging, these diseases may increase vulnerability or propensity for falls, especially with recurrent episodes ${ }^{(23)}$.

The occurrence of falls has multifactorial causes and increases linearly according to the number of risk factors. An investigation of 464 seniors in Natal, Rio Grande do Norte found that elderly people with no risk factors were $8 \%$ likely to fall, while those with four or more risk factors had a $78 \%$ chance of experiencing falls ${ }^{(24)}$. These results corroborate the findings of the present study.

In this study, the most prevalent intrinsic risk factors were history of falls, age $\geq 65$ years, cognitive impairment, visual impairment, impaired mobility and sleep deprivation. Extrinsic factors were the use of insufficient non-slip material in the bathroom and the use of loose carpets at home. In a study conducted in Alfenas, Minas Gerais, with 114 medical records of elderly subjects attended in the Elderly Care Program, was investigated the Risk for Falls ND. The study demonstrated a higher frequency of intrinsic factors, namely; age $\geq 65$ years, use of medications, impaired walking and history of falls, and also revealed $62 \%$ of extrinsic factors ${ }^{(13)}$.

A systematic review identified risk factors for fall in communitydwelling elderly according to NANDA-I Taxonomy II. Sixty-two articles were evaluated, in which the most prevalent intrinsic risk factors were pharmacological agents, gait modifications, impaired balance and visual deficit. Extrinsic factors included disorganized environment and use of insufficient non-slip material in the bathroom ${ }^{(25)}$.

A study conducted in Brasilia, Federal District, evaluated 271 institutionalized elderly and identified a prevalence of falls of $41 \%$. Among the risk factors present in NANDA-I Taxonomy II, foot problems and the gait were strongly correlated with falls in the elderly ${ }^{(26)}$. Gait modifications may be a strategy for increasing stability. With aging, the elderly person tends to modify the gait pattern and assume a decrease in normal arm balance, gait speed, step length, single foot support time, and an exaggerated external rotation of feet ${ }^{(27)}$.

Regarding cognitive function, in a study conducted in Juiz de Fora, Minas Gerais, was also found an association between cognitive impairment and falls, since the frequency of falls in the group with cognitive impairment was $42 \%{ }^{(28)}$. The association of cognitive impairment with falls in the elderly can be explained by the fact that motor and sensory systems are linked by neurological processes, which are related to the needed cognition for motor planning, dual-task attention and responses to environmental circumstances. Thus, elderly subjects with cognitive impairment may have impaired mobility and slower reaction to imbalances, and these aspects favor falls ${ }^{(29)}$.

Although in NANDA anemia is considered a physiological risk factor for falls, an interesting fact observed in this study was that anemic elderly were less likely to experience falls. However, were found no studies to corroborate this finding. Only seven elderly had anemia, and just two out of them reported episodes of fall.

The extrinsic factor that increased the risk for falls in the elderly in this study was the use of loose carpets. A study conducted in Foz do Iguaçu, Paraná with a sample of 350 elderly, also identified a statistically significant association between the occurrence of falls and the use of non-slip loose rugs in the kitchen and bedroom $^{(30)}$. Another study conducted in the Federal District evaluated the homes of 191 elderly and highlighted the following among environmental risk factors for falls in the elderly: lack of support for entering/leaving the bathroom and insufficient use of non-slip mats in the bathroom ${ }^{(31)}$.

The Risk for Falls ND has been poorly studied in the context of primary health care. However, results from other studies demonstrate the use of this ND in the scenario of hospitalized(7), institutionalized elderly ${ }^{(8)}$ or those in specific conditions, such as in patients with stroke ${ }^{(32)}$ or unstable angina ${ }^{(33)}$. 
Nursing diagnosis Risk for Falls in the elderly in primary health care Santos PHFS, Stival MM, Santos WS, Volpe CRG, Rehem TCMSB, Funghetto SS

\section{Study limitations}

The limitation of the study was the absence of home visits to identify environmental risk factors in the elderly's home. For future studies, is recommended an assessment of these aspects together with elderly subjects'self-reports of environmental factors.

\section{Contributions to the nursing area, health or public policy}

The present study contributed to fill a gap existing to date, of studies evaluating the Risk for Falls ND in the elderly in the context of primary health care. The results showed the importance of using this ND in primary care, especially in the elderly population, preferably in conjunction with additional instruments. The application of this ND in primary care will assist nurses in the initial assessment of risk for falls and guide the decision making in view of the identified risk factors, aiming at the prescription and implementation of specific and appropriate nursing interventions to the needs of every individual.

Considering that the studied sample presented high indices of history of falls and a high number of risk factors, mainly intrinsic, the role of nurses in the integral evaluation of the elderly is critical. These professionals should be aware of the inherent changes to the aging process and focus on the promotion of self-care and education of the elderly and their families regarding the risk for falls and damage prevention strategies. When addressing extrinsic risk factors, nurses and other members of the Family Health Strategy team have a key role in the observation of the home environment for identifying problems and promoting the safety of elderly subjects in their environments.

\section{CONCLUSION}

The study identified a high prevalence of history of falls in the elderly. In NANDA-I, the eight intrinsic risk factors related to history of falls were: age $\geq 65$ years, cognitive impairment, visual impairment, impaired mobility, sleep deprivation, impaired balance, and neuropathy. The extrinsic risk factors related to the history of falls were the use of insufficient non-slip material in the bathroom and the use of loose carpets in the house.

The intrinsic risk factors of NANDA-I that increased the risk for falls in the elderly with chronic diseases were: use of assistive devices, impaired walking, cognitive impairment and anemia. Regarding the extrinsic factor that increased the risk for falls in the elderly in this study, we highlight the use of loose carpets.

\section{FUNDING}

Fundação de Apoio a Pesquisa do Distrito Federal (FAP-DF). Conselho Nacional de Desenvolvimento Cientifico e Tecnológico (CNPq).

\section{REFERENCES}

1. World Health Organization - WHO. Envelhecimento ativo: uma política de saúde[Internet]. Brasília: Organização Pan-Americana da Saúde; 2005. 62 p. Available from: http://dms.ufpel.edu.br/ares/bitstream/handle/123456789/232/52005envelhecimento_ativo.pdf?sequence=1

2. Cavalcanti CL, Gonçalves MCR, Asciutti LSR, Cavalcanti AL. Envelhecimento e obesidade: um grande desafio no século XXI. Rev Bras Ciênc Saúde [Internet]. 2011 [cited 2017 Dec 14];14(2):87-92. Available from: http://www.periodicos.ufpb.br/ojs/index.php/rbcs/article/view/7230/5318

3. Ministério da Saúde (BR). Secretaria de Vigilância em Saúde, Departamento de Análise de Situações de Saúde. Plano de Ações Estratégicas para o Enfrentamento das Doenças Crônicas não Transmissíveis (DCNT) no Brasil 2011-2022. [Internet]. Brasília; 2011 [cited 2017 Dec 14]. 148 p. Available from: http://bvsms.saude.gov.br/bvs/publicacoes/plano_acoes_enfrent_dcnt_2011.pdf

4. Falsarella GR, Gasparotto LPR, Coimbra AMV. Quedas: conceitos, frequências e aplicações à assistência ao idoso. Revisão da literatura. Rev Bras Geriatr e Gerontol [Internet]. 2014 [cited 2017 Dec 14];17(4):897-910. Available from: http://www.scielo.br/pdf/rbgg/v17n4/1809-9823rbgg-17-04-00897.pdf

5. Gauterio DP, Zortea B, Santos SS, Tarouco BS, Lopes MJ, Fonseca CJ. Risk factors for new accidental falls in elderly patients at Traumatology Ambulatory Center. Invest Educ Enferm [Internet]. 2015 [cited 2018 Aug 6];33(1):35-43. Available from: http://www.scielo.org.co/pdf/iee/ v33n1/v33n1a05.pdf

6. NANDA International. NANDA International nursing diagnoses: definitions and classification 2015-2017. Herdman TH, Kamitsuru S, organizadores. Porto Alegre: Artmed; 2015.

7. Luzia MF, Victor MAG, Lucena AF. Nursing Diagnosis Risk for falls: prevalence and clinical profile of hospitalized patients. Rev LatinoAm Enfermagem [Internet]. 2014 [cited 2017 Nov 29];22(2):262-8. Available from: http://www.scielo.br/pdf/rlae/v22n2/0104-1169rlae-22-02-00262.pdf

8. Reis KMC, Jesus CAC. Relação da polifarmácia e polipatologia com a queda de idosos institucionalizados. Texto Contexto Enferm [Internet]. 2017 [cited 2018 Apr];26(2). Available from: http://www.scielo.br/pdf/tce/v26n2/pt_0104-0707-tce-26-02-e03040015.pdf

9. Bezerra F, Lemos STM, Sousa AC, Carvalho SML, Fernandes CMC, Alves AFS, Dalva M. Promoção da saúde: a qualidade de vida nas práticas da enfermagem. Enferm Glob [Internet]. 2013 [cited 2018 Apr 10];23:270-9. Available from: http://scielo.isciii.es/pdf/eg/v12n32/pt_ensayos2.pdf

10. Sociedade Brasileira de Diabetes - SBD. Diretrizes da Sociedade Brasileira de Diabetes 2015-2016. [Internet] 2015 [cited 2018 Mar 18]. Available from: http://www.diabetes.org.br/profissionais/images/docs/DIRETRIZES-SBD-2015-2016.pdf

11. World Health Organization - WHO. Iron deficiency anaemia: assessment, prevention and control: a guide for programme managers[Internet]. 2001 [cited 2018 Mar 18]. Available at: http://pesquisa.bvsalud.org/portal/resource/pt/who-66914 
Nursing diagnosis Risk for Falls in the elderly in primary health care Santos PHFS, Stival MM, Santos WS, Volpe CRG, Rehem TCMSB, Funghetto SS

12. Melo DM, Barbosa AJG. O uso do Mini-Exame do Estado Mental em pesquisas com idosos no Brasil: uma revisão sistemática. Cienc Saude Colet [Internet]. 2015 [cited 2018 Mar 11];20(12):3865-76. Available from: http://www.scielo.br/pdf/csc/v20n12/1413-8123-csc-20-12-3865.pdf

13. Chaves ECL, Cordeiro LAM, Goyatá SLT, Godinho MLSC, Meirelles VC, Nascimento AM. Identificação do diagnóstico risco de quedas em idosos atendidos pelo Programa de Atenção ao Idoso. Rev Enferm UFPE [Internet]. 2011 [cited 2018 Apr 8];5(10):2507-2514 p. Available from: https://periodicos.ufpe.br/revistas/revistaenfermagem/article/download/6971/6220

14. Reis LA, Rocha TS, Duarte SFP. Quedas: risco e fatores associados em idosos institucionalizados. Rev Baiana Enferm [Internet]. 2014 [cited 2018 Mar 11];28(3):225-34. Available from: https://portalseer.ufba.br/index.php/enfermagem/article/viewFile/12303/8982

15. Miyamoto ST, Lombardi Jr I, Berg KO, Ramos LR, Natour J. Brazilian version of the Berg balance scale. Brazilian J Med Biol Res [Internet]. 2004 [cited 2018 Mar 11];37(9):1411-21. Available from: http://www.scielo.br/pdf/bjmbr/v37n9/5292.pdf

16. Karuka AH, Silva JAMG, Navega MT. Analysis of agreement of assessment tools of body balance in the elderly. Rev Bras Fisioter [Internet]. 2011 [cited 2018 Mar 11];15(6):460-6. Available from: http://www.scielo.br/pdf/rbfis/v15n6/en_v15n6a06.pdf

17. Pedrosa HC. Polineuropatia Diabética: novas estratégias para diagnóstico e intervenção terapêutica precoces - Diretrizes NeurALAD. Argentina; 2010 [cited 2018 Apr 4]. Available from: http://www.anad.org.br/wp-content/uploads/2015/07/Highlight_CODHy_Buenos_ Aires_Dra_Hermelinda_Pedrosa_7505.pdf

18. Borba AKOT, Marques APO, Ramos VP, Leal MCC, Arruda IKG, Ramos RSPS, et al. Factors associated with elderly diabetic adherence to treatment in primary health care. Cienc Saude Colet [Internet]. 2018 [cited 2018 Apr 6];23(3):953-61. Available from: http://www.scielo.br/ pdf/csc/v23n3/en_1413-8123-csc-23-03-0953.pdf

19. Instituto Brasileiro de Geografia e Estatística - IBGE. Síntese de Indicadores Sociais: uma análise das condições de vida da população brasileira[Internet]. 2013 [cited 2018 Apr 6]. Available from: https://biblioteca.ibge.gov.br/visualizacao/livros/liv66777.pdf

20. Gavasso WC, Beltrame V. Functional capacity and reported morbidities: a comparative analysis in the elderly. Rev Bras Geriatr e Gerontol [Internet]. 2017 [cited 2018 Apr 6];20(3):398-408. Available from: http://www.scielo.br/pdf/rbgg/v20n3/1809-9823-rbgg-20-03-00398.pdf

21. Vieira LS, Gomes AP, Bierhals IO, Farías-Antúnez S, Ribeiro CG, Miranda VIA, et al. Falls among older adults in the South of Brazil: prevalence and determinants. Rev Saude Publica [Internet]. 2018 [cited 2018 Apr 9];52:22. Available from: http://www.revistas.usp.br/rsp/article/view/143831/138461

22. Chiang GSH, Sim BLH, Lee JJM, Quah JHM. Determinants of poor sleep quality in elderly patients with diabetes mellitus, hyperlipidemia and hypertension in Singapore. Prim Health Care Res Dev [Internet]. 2018 [cited 2018 Apr 6];1-6. Available from: http://www.ncbi.nlm.nih.gov/ pubmed/29580302

23. Nascimento JS, Tavares DMS. Prevalence and factors associated with falls in the elderly. Texto Contexto Enferm [Internet]. 2016 [cited 2017 Dec 14];25(2). Available from: http://www.scielo.br/pdf/tce/v25n2/en_0104-0707-tce-25-02-0360015.pdf

24. Santos RKM, Maciel ACC, Britto HMJS, Lima JCC, Souza TO. Prevalência e fatores associados ao risco de quedas em idosos adscritos a uma Unidade Básica de Saúde do município de Natal, RN, Brasil. Cienc Saude Colet [Internet]. 2015 [cited 2018 Apr 7];20(12):3753-62. Available from: http://www.scielo.br/pdf/csc/v20n12/1413-8123-csc-20-12-3753.pdf

25. Sousa LMM, Marques-Vieira CMA, Caldevilla MNGN, Henriques CMAD, Severino SSP, Caldeira SMA. Risco de quedas em idosos residentes na comunidade: revisão sistemática da literatura. Rev Gaúcha Enferm [Internet]. 2016 [cited 2018 Apr 7];37(4). Available from: http://www. scielo.br/pdf/rgenf/v37n4/en_0102-6933-rgenf-1983-144720160455030.pdf

26. Reis KMC. Avaliação de risco de queda em população idosa institucionalizada[Internet]. 2014 [cited 2018 Apr 9]. Available from: http://www. repositorio.unb.br/handle/10482/16848

27. Silva TL, Martinez EZ, Junior APS, Manço ARX, Arruda MF. A associação entre a ocorrência de quedas e a alteração de equilíbrio e marcha em idosos. Rev Saúde Pesqui [Internet]. 2014 [cited 2018 Apr 8];7(1). Available from: http://periodicos.unicesumar.edu.br/index.php/saudpesq/ article/view/3169/2206

28. Teles Da Cruz D, Moreira Da Cruz F, Ribeiro AL, Lagrotta C, Veiga D, Cristina I, et al. Associação entre capacidade cognitiva e ocorrência de quedas em idosos [Internet]. 2015 [cited 2018 Apr 8];23(4):386-93. Available from: http://www.scielo.br/pdf/cadsc/v23n4/1414-462X-cadsc-23-4-386.pdf

29. Bortoli CG, Piovezan MR, Piovesan EJ, Zonta MB. Balance, falls and functionality among elderly persons with cognitive function impairment. Rev Bras Geriatr Gerontol [Internet]. 2015 [cited 2018 Apr 7];18(3):587-97. Available from: http://www.scielo.br/pdf/rbgg/v18n3/en_18099823-rbgg-18-03-00587.pdf

30. Pereira SG, Santos CB, Doring M, Portella MR, Portella MR. Prevalence of household falls in long-lived adults and association with extrinsic factors. Rev Latino-Am Enfermagem [Internet]. 2017 [cited 2017 Dec 14];25(0):e2900-. Available from: http://www.scielo.br/pdf/rlae/v25/01041169-rlae-25-e2900.pdf

31. Lourenço TS, Lima LR, Santos WS, Souza JMO, Funghetto SS, Karnikowski MGO, et al. Environmental risk factors for falls in the elderly residents of Ceilândia-DF. Rev Mov [Internet]. 2013 [cited 2018 Mar 18];6(2):1984-4298. Available from: http://www.nee.ueg.br/seer/index. php/movimenta/article/viewFile/670/507

32. Morais HCC, Holanda GF, Oliveira ARS, Costa AGS, Ximenes CMB, Araujo TL. Identificação do diagnóstico de enfermagem risco de quedas em idosos com acidente vascular cerebral. Rev Gaúcha Enferm [Internet]. 2012 [cited 2018 Apr 7];33(2):117-24. Available from: http://www. scielo.br/pdf/rgenf/v33n2/17.pdf

33. Vitor AF, Lopes MVO, Araujo TL. Diagnóstico de enfermagem risco de quedas em pacientes com angina instável. Rev Rene [Internet]. 2010 [cited 2018 Mar 18];11(1). Available from: http://periodicos.ufc.br/rene/article/view/4484/3392 